\title{
7 A Literary and Discourse Analysis of Psalm 110
}

As shown in the previous three chapters, reading a text with its co-text(s) together helps a reader to understand the text at hand. Understanding Psalm 110 is no exception; thus, this approach will be taken here. Given that Psalm 110 is a selfcontained unit, we propose the following. In this chapter, Psalm 110 will be viewed in light of discourse and rhetorical-literary analysis, with emphasis placed on its poetic nature. Likewise, in the following two chapters, we fill focus our study on Psalm 110 in its cotexts, namely, the Psalter as a whole and Book V of the Psalter, after discussing recent studies on the structure and shape of the Psalter. Furthermore, we will exegetically attend to Psalms 2 and 132 because of their unmistakably close semantic-thematic relationship to Psalm 110. Then, to conclude, we will synthesize chapters seven to nine in order to extract any theological implications of this study in view of the overarching ברך-theme in God's covenantal promise.

\subsection{A Poetic and Rhetorical Study of Psalm 110}

Psalm 110 is a crucial psalm on which much research and study has been done. One way of explaining this intense interest is the text of Psalm 110, which is a challenge with its many textual difficulties ${ }^{408}$ and is far from easy to interpret. The main explanation, however, is that parts of Psalm 110 are often quoted by the early Christian literature. ${ }^{409}$ For instance, this Psalm is often quoted in the $\mathrm{NT}^{410}$ mainly for its eschatological and messianic implications. Particularly in the NT, v. 1 is quoted 19 times: five citations and 14 allusions. ${ }^{411}$ Nonetheless, some scholars have rejected the messianic reading of Psalm 110 by the NT, ${ }^{412}$ specifically calling the usage of Psalm 110 in Hebrews a

\footnotetext{
408 Raymond Tournay, "Le Psaume CX," RB 67 (1960): 5. He aptly describes: "D’innombrabes etudes ont deja essaye de rendre intelligibles le sept versets de ce psaume si court, mais si difficile." Mitchell Dahood notes: "Though the Hebrew text teems with difficulties, and the consequent interpretation of some details remains uncertain, it should not be described as 'unusually corrupt,' an evaluation put upon it by The Oxford Annotated Bible the RSV, ed. by H. G. May and B. M. Metzger (Oxford, 1962)." See his Psalms III: 101-150, AB, vol. 17A (Garden City, N.Y.: Doubleday \& Company, Inc., 1970), 112-13. 409 See David Hay, Glory at the Right Hand: Psalm 110 in Early Christianity (Nashville, Tenn.: Abingdon, 1973), 163-66. In his book, he lists all the references that contain direct quotes of or allusions to Psalm 110.

410 Leslie Allen, Psalms 101-150, WBC, vol. 21 (Waco, Tex.: Word Books, 1983), 87. There he remarks: "[This psalm] holds the record for being the OT text most frequently cited or alluded to in the NT."

411 Mark Saucy, "Exaltation Christology in Hebrews," TrinJ 14 (1993): 43.

412 For example, Hans-Joachim Kraus, Psalms 60-150: A Commentary, trans. Hilton Oswald (Minneapolis, Minn.: Augsburg Fortress, 1989), 353.
} 
midrash. ${ }^{413}$ How we are to understand this Psalm is one of our pressing goals in this project. Should it be read messianically or merely historically is the objective we have in mind to achieve in this chapter.

Analyzing Psalm 110 from a genre perspective is not smooth sailing. Many regard Psalm 110 as a royal psalm ${ }^{414}$ though it contains some descriptive elements of the enthronement festivals. ${ }^{415}$ Yet the debate of how to define a royal psalm is yet to reach a definitive conclusion. For instance, Scott Starbuck has examined the past 150 years of scholarship in his search for a definition of royal psalms and about all he can safely conclude is that scholars share a "significant definitional disagreement." ${ }^{\text {"16 }}$ It is not this chapter's focus to define either the historical background - including dating - of the text or the Sitz im Leben of Psalm 110. Our interest is two-fold: (1) we will study the final form of the text even though it is plagued with textual difficulties in some verses, and (2) we will concentrate our study on how the canonical shape (the final form) of the Psalter sheds light on this Psalm (the work of the next two chapters). We will now turn to the textual problems in Psalm 110.

\subsubsection{Textual Notes for Psalm 110}

The textual variants may be crucial to our interpretation of the poem, and therefore deserve some discussion. Among the seven verses, v. 3 contains the most textual problems. Since v. 3 and the textual variants there involve a major interpretation of the psalm, we will evaluate them later in this paper. Six noticeable variants are indicated below: ${ }^{417}$

The first textual variant involves a different reading of the Hebrew vowel points: the LXX uses the phrase $\mu \in \tau \dot{\alpha}$ бov̂ to reflect a reading of ("with you") instead of the MT’s עַפְּר ("your people”).

413 See Joseph Fitzmyer, "'Now This Melchizedek . . ' (Heb 7, 1),” CBQ 25 (1963): 305; Harold W. Attridge, The Epistle to the Hebrews, Hermeneia (Philadelphia: Fortress, 1989), 186; Lane, Hebrews 1-8, 159; Graham Hughes, Hebrews and Hermeneutics: The Epistle to the Hebrews as a New Testament Example of Biblical Interpretation (Cambridge: Cambridge University Press, 1979), 14. We will address the use of Psalm 110 in Hebrews in our chapters 10 and 11.

414 Just one example is sufficient to show the majority opinion that Psalm 110 is a royal song. See Allen, Psalms 101-150, 83.

415 Hans-Joachim Kraus, Psalms 60-150, 347. For Kraus, v. 1 and v. 4 clearly contain these enthronement elements. Cf. his Theology of the Psalms, trans. Keith Crim (Minneapolis, Minn.: Augsburg, 1986), 111. 416 Scott R. A. Starbuck, Court Oracles in the Psalms: The So-Called Royal Psalms in Their Ancient Near Eastern Context, SBLDS 172 (Atlanta, Ga.: SBL, 1999), 66. According to Starbuck, credit should be given to Herman Gunkel for his "recognition of a distinct class of bona fide royal psalms." Ibid., 2. Also Starbuck, in the first chapter of his book, delineates several key scholars' views on the genre of the royal psalm.

417 Please refer to the critical apparatus of Psalm 110 in BHS. 
Second, the LXX's $\dot{\eta}$ גִ גִיבָה ("dignity") offering").420 If one follows the LXX, the phrase עמרך נדבת (421 is then rendered "with you is your nobility (dominion)," while if one follows the MT, the phrase is rendered "your people is willing."

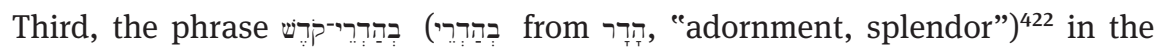

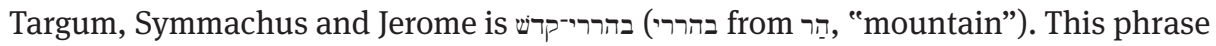
בהררי־קדש can only be found in Ps 87:1. Nonetheless, the LXX ( $2 \alpha \mu \pi \rho o ́ \tau \eta \sigma \iota \nu) ~ s u p p o r t s$ the MT reading.

Fourth, the word מִשְָׁ, though regarded as a hapax legomenon, ${ }^{423}$ is rendered by

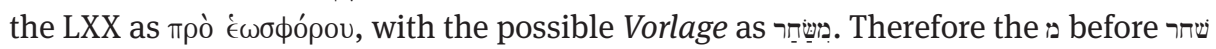
could be a dittography. ${ }^{424}$

Fifth, our next textual variant in v. 3 is an omission in the Greek translation of the

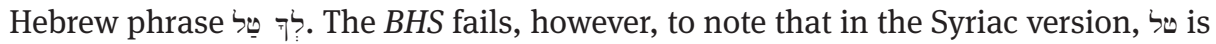
spelled as טלי ${ }^{425}$

Sixth, the final variant of v. 3 also involves a change of vowel point. The LXX, supported by other textual traditions (Origen, Theodotian, Syriac), uses '́ $\xi_{\xi} \epsilon \gamma^{\prime} \nu \nu \eta \sigma \alpha \dot{\alpha} \sigma \epsilon$,

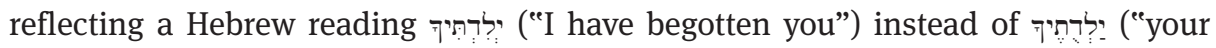
youth").

\footnotetext{
418 LSJ, 252.

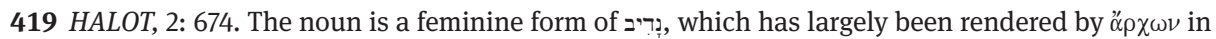
the LXX.

420 HALOT, 2: 672. See Elmar Santos, The Expanded Hebrew Index for the Hatch-Redpath Concordance to the Septuagint (Jerusalem: Dugith, n.d.), 129. Cf. Takamitsu Muraoka, Hebrew/Aramaic Index to the Septuagint: Keyed to the Hatch-Redpath Concordance (Grand Rapids, Mich.: Baker Books, 1998), 93. The Hebrew word נִדָּד has never been rendered as $\dot{\alpha} \rho \chi \eta$ in the LXX but translated by the following

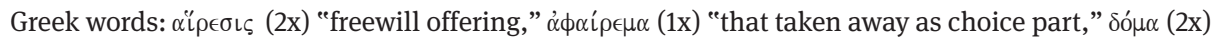

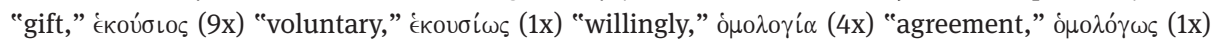

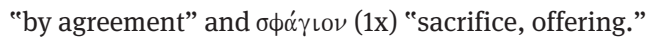

421 Note that the Hebrew consonantal text is unchanged.

422 HALOT, 1: 240.

423 See BDB, 1007. There the word is treated as a noun but associates with שָׁ cf. HALOT, 2: 644. See also Allen, Psalm 101-150, 80 and Hans Joachim Stoebe, "Erwägungen zu Psalm 110 auf dem Hintergrund von 1 Sam 21," in Festschrift Friedrich Baumgärtel zum 70. Geburtstag, ed. Johannes Herrmann (Erlangen: Universitätsbund, 1959), 188.

424 It is thus suggested by BHS. On the other hand, some see משחר as possible paronomasia with משיח ("anointed"). See Raymond J. Tournay, Seeing and Hearing God with the Psalms, trans. J. Edward Crowley (Sheffield: Sheffield Academic Press, 1991), 213. Others like Joachim Schaper see the use of

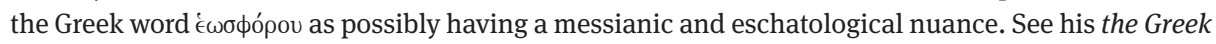
Psalter, 102.

425 A. Caquot provides a list of textual interpretations for v. 3 and he points out the "resemblance" of של של and. See his "Remarques sur le Psaume CX," Sem 6 (1956): 41, footnote 1. 


\subsection{A Rhetorical-Poetical Analysis of Psalm 110}

Psalm 110 is a closely knitted text and its writer is a brilliant poet whose skill in composition awaits analysis. The employment of a rhetorical analysis will be sensitive to the poetic nature of this text. Besides a grammatical-syntactical analysis, we will pay attention to word-play or sound-play, strophic analysis, parallelism, rhetorical devices, and linguistic features. ${ }^{426}$ We divide this study of the Psalm 110 text into six parts: first, we will the poetic structure within each verse (intra-verse connectives); next, we will look into the poetic structure evidenced between verses (inter-verse connectives); the third task we will perform is a strophic structure analysis; fourth, we will engage in an overall rhetorical-structure analysis; fifth, we will do a word and syllable count; and in our last section, we will devote time to theological reflections based upon the poetic analysis.

\subsubsection{A Poetic Structure Analysis: Intra-Verse Connectives}

The poet has professionally crafted Psalm 110 using various literary and poetic techniques. One can at least detect several of these techniques employed within a verse itself in each of Psalm's seven verses.

In v. 1, each smaller unit ends with either 'ִ or or as the layout below shows:

v. $1 \mathrm{~b} \alpha$ and $1 \mathrm{~b} \beta:$ :

v. 1 b $\gamma$ and $1 b \delta: \tau^{\prime}, \tau^{\prime}, . .427$

In addition, the verse is linked by the imperfect-imperative of שִית-יָישב (both similar

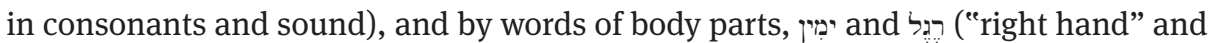

426 Adele Berlin has developed many categories for poetry analysis, and we will utilize some of her categories in this project. See her The Dynamics of Biblical Parallelism (Bloomington and Indianapolis, Ind.: Indiana University Press, 1985). More recently, J. F. Fokkelman has done a major study using syllable count and other text-linguistic devices on selective poetic texts, including Psalm 110. See his Major Poems of the Hebrew Bible: At the Interface of Prosody and Structural Analysis, Vol. 2, 85 Psalms and Job 4-14 (Assen, Netherlands: Van Gorcum, 2000). Cf. his early work where the first chapter lays out his theoretical framework based on a linguistic-inspired text model in his Major Poems of the Hebrew Bible: At the Interface of Hermeneutics and Structural Analysis, Vol. 1, Ex. 15, Deut. 32, and Job 3 (Assen, Netherlands: Van Gorcum, 1998).

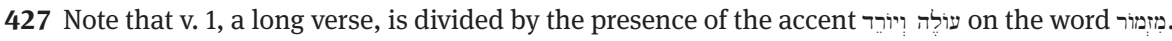


"foot"). Dahood also observes how there is an assonance as well as an alliteration ${ }^{428}$

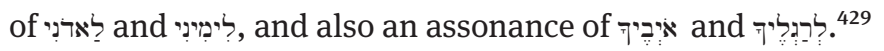

In v. 2, the line is linked by the imperative-imperfect of רדָָה-שָׁלָ לoth have their own adverbial phrases ("from Zion" and "in the midst of your enemies" respectively).

In v. 3, the picture is a bit unclear and complicated..$^{430}$ If one takes out מֶרֶים מִשְחר, we have the following chiastic structure:

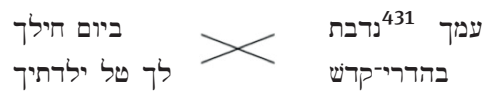

Note how the chiasm is formed by the consonant $\geq$ and $>$ in the initial position of

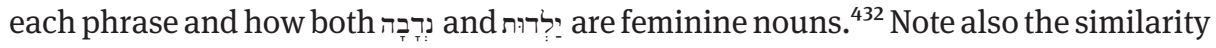
of the consonants in the phrase משרחם משחר. 433 Another way to dissect this verse is as follows (italics ours):

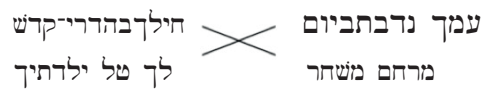

Note also the chiasm formed by two घ's with two z's and $2 .{ }^{434}$ We prefer to read v. 3 in this way because it retains the phrase מרחם משחר in the structure; furthermore, this chiastic parallel may assist us as we interpret this difficult verse later in our study.

In v. 4, ינחבע and are both in ni. (perfect and imperfect respectively). It is a parallel of the same conjugation (i.e., ni.) with a different stem and tense. ${ }^{435}$ The rest of v. 4 can be paired as follows (italics ours):

428 Stanislav Segert has attempted to define assonance and alliteration (plus rhyme) in his article titled "Assonance and Rhyme in Hebrew Poetry," MAARAV 8 (1992): 171-79. Simply put, "alliteration is the repetition of consonant sounds, assonance is the repetition of vowel sounds, and rhyme is the repetition of combinations containing both consonants and vowels" (ibid., 172). He regards these literary devices as part of the parallelism in Hebrew poetry.

429 Dahood, Psalms III, 113-14.

430 Verse 3 ends the first strophe of this text and it may be a triadic. According to Robert Alter, the function of a triadic line in a typical dyadic system is two-fold: "to mark some special emphasis or to indicate the beginning or conclusion of a segment. ..." See his Biblical Poetry, 35. Cf. Fokkelmann, 85 Psalms, 289-90, where he compares v. 2 and v. 3 in a tricola fashion.

431 The plural noun נדבת is there for emphasis. See GKC, \$141c.

432 F. Delitzch regards ילדתיך הילד and as parallel. See his Biblical Commentary on the Psalms, trans. F. Bolton, vol. 3 (London: Hodder and Stroughton, 1887-89; reprint, Grand Rapids, Mich.: Eerdmans, 1980), 191.

433 The phrase is "highly poetic and unusual" according to Willem VanGemeren. See VanGemeren, "Psalms," EBC, vol. 5 (Grand Rapids, Mich.: Zondervan, 1991), 698.

434 Cf. P. Leo Krinetzki, “Ps 110 (109): Eine Untersuchung seines dichterischen Stils,” TGl 51 (1961): 118.

435 Berlin, Biblical Parallelism, 33-35. 


$$
\text { אתה כהן לעולם }
$$

Krinetzki sees a chiastic structure for the above text: ${ }^{436}$

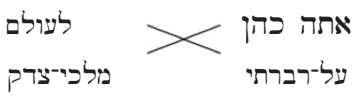

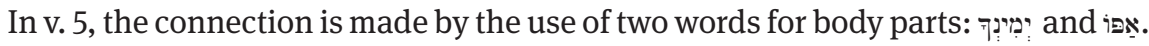
The verse is structured by a parallel of a substantive (v. $5 \mathrm{a}$ ) to its verbal form (v. 5b). ${ }^{437}$

In v. 6, the similarity in consonants between the two words, בגויות should be noted. The, verse can be read as

$$
\text { מחי ראשי }
$$

The parallels are nations//head(s); filling corpses//over a wide earth. The first parallel has a semantic "specification" (that is, the nations are judged for their heads are smitten), while the second parallel has "consequentality" (the dead are so many that they fill a wide geographical area). ${ }^{438}$ The two lines are also paired by a shift of the imperfect to the perfect (yqtl-qtl). ${ }^{439}$

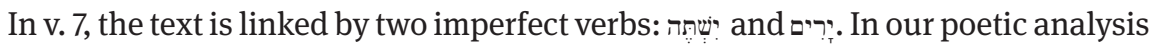
we will now turn to inter-verse connections.

\subsubsection{A Poetic Structure Analysis: Inter-Verse Connectives}

The poet has attempted to connect two verses by using various literary devices and techniques. ${ }^{440}$ Between v. 1 and v. 2, there is a chiastic parallel of tenses: imperativeimperfect (v. 1) and imperfect-imperative (v. 2). There is a re-appearance of this word איבֶיך. Between v. 2 and v. 3, there is a word-play of הדר and abserve the reversal of $\pi$ and $\urcorner$ in these two words, and note also how between v. 3 and v. 4, there is another

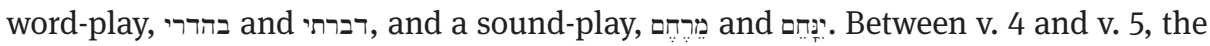
word מלך is found in the proper noun (Melchizedek) and the object (kings) of the Lord's striking due to His anger. Between v. 5 and v. 6, the word מחיץ appears. Furthermore, there seems to be a parallel in these two verses, as indicated in the following:

436 Krinetzki, "Ps 110 (109),” 119.

437 See Berlin, Biblical Parallelism, 54-55.

438 Ibid., 29. See Berlin's categories there.

439 Ibid., 36.

440 Cf. Fokkelman, 85 Psalms, 289 (footnote 97). 
v. 5a: אדני על-ימינד

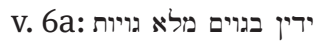

The consonant, appears twice in both ידין מינד מויות and The following layout applies to v. $5 \mathrm{~b}$ and v. $6 \mathrm{~b}$ :

\section{v. 5b: מחיץ ביום־אפו מלכים}

v. 6b: מחץ ראש על-ארץ רבה ביום מלבים

It appears that these two verses are strongly linked by the same verb, פמחץ "shatter" (same tense) and body parts, אפש ("anger," literally, "nose" and "head"). Between v. 6 and v. 7, the word ראש is the connecting word: the first one can be taken figuratively ("head" or "heads" as parallel to "kings" in v. 5) while the other physically, "he lifts up his head." Our skilled poet does not overlook an opportunity to also play

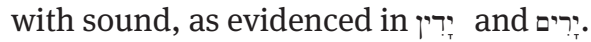

The construction of vv. 5-7 is worthy of comment. ${ }^{441}$ The grammatical-lexical patterning is of particular note: ${ }^{442}$

v. 5b: shatter (qtl) ... kings

v. 6b: shatter (qtl) ... head

v. 7b: lift up (yqtl) ... head

Semantically speaking, vv. 5-6 can be called a "structure of intensification" because the divine anger not only shatters kings but also heaps up corpses in the nations spread over a wide geographical location ("wide earth"). ${ }^{443}$

\subsubsection{A Poetic Structure Analysis: The Structure of Two Strophes}

Psalm 110 can be divided into two parts: vv. 1-3 and vv. 4-7; noticeably, both strophes are

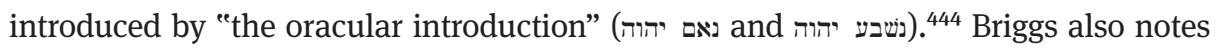

441 Two articles focus on vv. 5-7: Maurice Gilbert and Stephen Pisano, “Psalm 110 (109), 5-7,” Bib 61 (1980): 343-56. Their finding is echoed by Pierre Auffret, "Note sur la structure littéraire du Psaume CX,” Sem 32 (1982): 83-88. Both articles are helpful to identify who’s who in vv. 5-7.

442 Berlin, Biblical Parallelism, 83-88.

443 Alter, Biblical Poetry, 64-65.

444 Allen, Psalms 101-150, 85. Klaus Seybold treats v. 1a (לדיְדר מזְמור) as a superscription but also divides the poem into two strophes. See his Die Psalmen, HAT I/15 (Tübingen: Mohr, 1996), 438. Not all scholars see the poem as composed of two strophes. The range of strophes numbers from three to five. For examples, Fokkelman analyzes the poem as containing four strophes. See his 85 Psalms, 288, 528. Simone Springer has 5 strophes for this poem. See his Neuinterpretation im Alten Testament: Untersucht an den Themekreisen des Herbstfestes und der Königspsalmen in Israel, SBB (Stuttgart: Katholisches Bibelwerk GmbH, 1979), 140. For authors who propose a three-strophe structure, see Allen, Psalms 101-150, 85. On the contrary, some see the oracular introductions in vv. 1, 4 as inclusio, thus marking vv. 1-4 as one unit while vv. 5-7 comprises another unit. For example, Tournay remarks that "the oracle (vv. 1-4) is followed by a sort of commentary (vv. 5-7)" in his Seeing and Hearing, 209. Similarly, see James Kurianal, Jesus Our High Priest: Ps 110, 4 as the Substructure of Heb 5, 1-7, 28, EU 693 (Frankfurt: Peter Lang, 2000), 30-31. 
that some lines in both strophes end with $\mathrm{n}, \mathrm{s}, 7$, and,${ }^{445}$ The first strophe links to the second by word-play (common in consonants) or sound-play as set forth in figure 3:

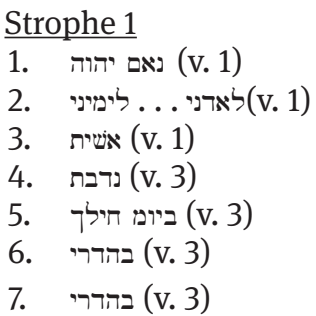

\section{Strophe 1}

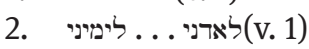

3. אשית (v. 1)

4. נדבת (v. 3)

5. ביומ חילך (v. 3)

7. בהדריר (v. (v. 3)

Strophe 2
1. נשבע יהוה (v. 4)
2. ארני על־יימינות (v. 5) (v. (v)
3. ישתה (v. 7)
4. דברת (v. 4)
5. ביומדיאפו (v. 5)
6. רברת (v. 4)
7. בררך (v. 7)

Figure 3. Strophic Links of Psalm 110

Some observation notes are due here: 1 . For 3, both words contain $\pi$, ש, $\cdot$. 2. For 4, both

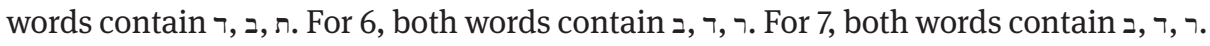

Furthermore, for strophe 1, besides the inner connectives previously noted, we should add that the connection of all these verses is made by means of assonance: ${ }^{446}$

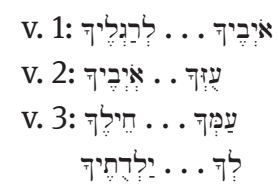

Regarding strophe 2, we add three more comments when considering the inner structure of this strophe. First, there is the similarity of consonants between ינחי ("he will not change his mind") in v. 4 and ("from the brook") in v. 7; second, there is

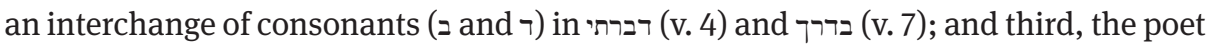
uses על in all four verses (vv. 4, 5, 6, 7). ${ }^{447}$

Thus far our poetic-literary analysis reveals how this Psalm is closely knit together. Yet among all these detailed observations, one should not lose sight of the rhetorical arrangement and its effect on the Psalm.

\subsubsection{A Rhetorical Structure of Psalm 110}

The poem seems to have an overall rhetorical structure based on parallel semantic words and the use of literary devices (word- or sound-plays). ${ }^{448}$ We are presented

445 C. A. and E. G. Briggs, A Critical and Exegetical Commentary on the Book of Psalms, ICC, vol. 2 (New York: Charles Scribner's Sons, 1907), 375.

446 Cf. Dahood, Psalms III, 116 and Allen, Psalms 101-150, 85.

447 This is also noted by Allen in Psalms 101-150, 85.

448 It is not necessary to defend the unity of the poem with all these semantic links between the two strophes and various parts of the poem. See J. Doré, "L'évocation de Melchiséech et le problème de l'origine du Psaume 110," Transeuphratène 15 (1998): 28-29. 
with three possibilities for viewing this poem rhetorically, and we will evaluate each option and choose what we think is best. ${ }^{449}$

The first option is without the oracle formulae, rendering it ABCD//D'C'B'A' in the following layout:

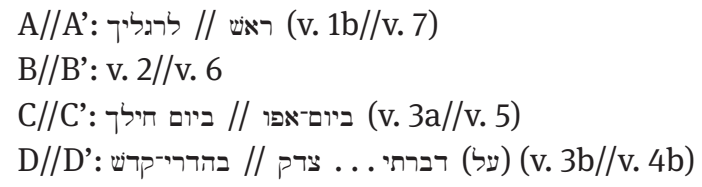

In this concentric chiastic structure, the maximum rhetorical effect will be on vv. 3-4 by beginning and ending the poem with the choice of words pertaining to bodyparts ("foot" and "head") in A//A'. In C//C', the link between v. $3 a$ and v. 5 is quite obvious by this exact phrase ("in the day of"). For D//D', the play on similar consonants binds v. $3 \mathrm{~b}$ and v. $4 \mathrm{~b}$ together. Nonetheless, there are some drawbacks to this structure. First and foremost is the omission of the oracular introductions in this analysis. A second concern is that part of v. 4, ולא ינחם אתה־כהן לעולם, remains unaccounted for in this option.

The second structural analysis includes the oracular formulae, and, to illustrate, the poem will appear in the structure of ABCDE//A'B'C'D'E':

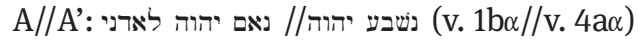

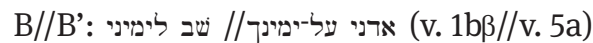

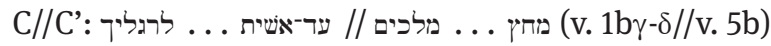

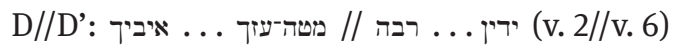
E//E': v. 3//v. 7

For A//A', the oracular formulae in both verses are very clear as the starting point; however, the little phrase xny alw ("and he will not change his mind") in v. 4 remains unaccounted for in this analysis.For B//B', the "right hand" signifies the parallelism in both phrases. For C//C', the identity of "enemies" in v. 1 (also in v. 2) now becomes clear in v. 5, i.e., "kings." For D//D', the extent of the "rule" (signified by the "scepter sent by the Lord") seems to be defined by "over the nations" and "upon a wide earth." The major deficiency of this structural analysis is that a major part of v. 4, qdc ... alw, is not included.

The third option is a combination of the above two. Figure 4 shows the layout for Psalm 110 with the exception of the superscription (לדְִָ מִזְמוֹר):

449 Marc Girard refers to this poem as "grand diptyque” and also proposes several structural layouts for this poem. Idem, Les Psaumes Redécouverts: De la structure au sens (Montréal: Bellarmin, 1994), 161, cf. 160-64. 


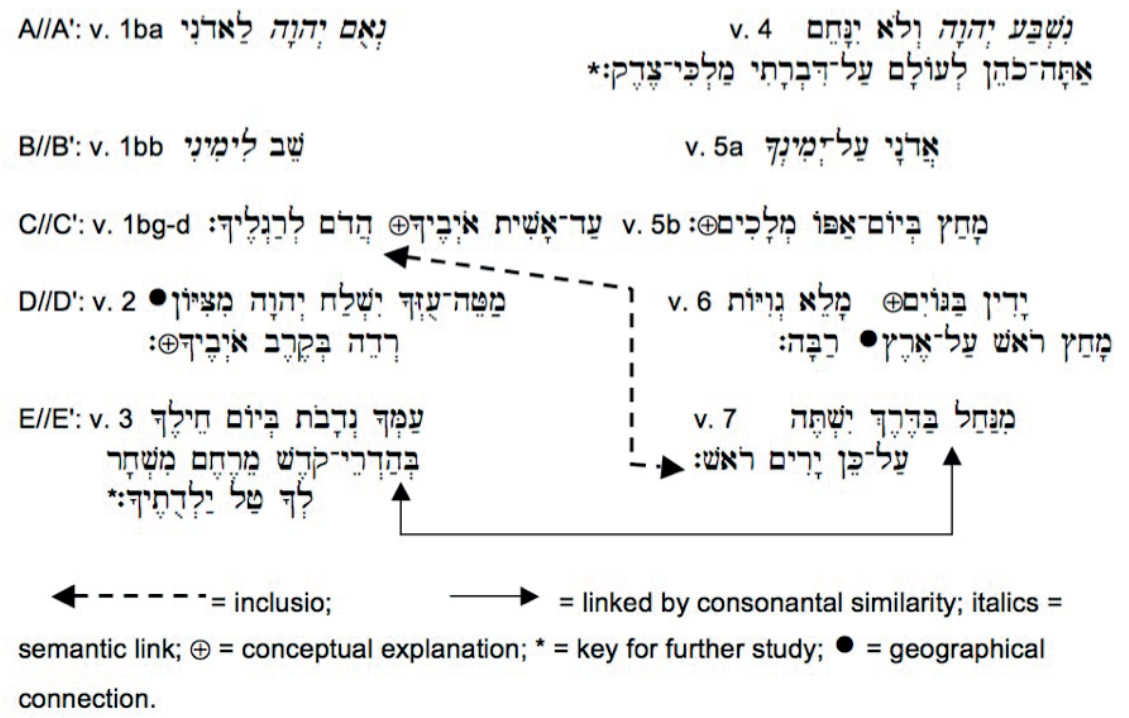

Figure 4. Rhetorical Layout of the MT text of Psalm 110

This layout has several advantages exegetically. First, as noted earlier, the body-part in v. 1 and v. 7 serves as inclusio ("foot" and "head"). ${ }^{450}$ Second, every word in the poem is accounted for in this rhetorical parallel structure. Third, each pair reveals something that could not be detected by simply reading the text. Therefore, we will reiterate some of the important observations next in view of this layout.

Each pair is connected through literary devices. Skipping AA', v. 1bb and v. 5a are obviously linked by the key word "right hand" in BB' though the identity in v. 5 needs to be clarified later. For CC' and DD', please refer to our second option above (also labeled as CC' and DD' there). Furthermore, DD' is linked by two geographical locations: "from Zion" and "on the wide earth." Again the "enemy" in v. 2 is further marked by "the nations." ${ }^{451}$ For EE', the only link evidenced in the paired verses is their shared consonantal similarity. Yet, if read carefully, both verses may display some mythical elements, ${ }^{452}$ further aided by the textual difficulty in v. 3 and also by the problematic identity of the person who "drinks ... and lifts up his head."

450 Alter may call this "envelope structure." See his Biblical Poetry, 56. The inclusio is further

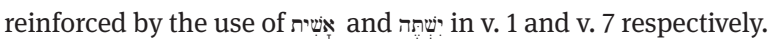

451 Note how the structure of this phrase בקרב איביך begins with ב cf. the same preposition prefixed to the word בגוים.

452 See Starbuck, Court Oracles, 149-53. There Starbuck notes the influence of the mythological element from the ANE and Egyptian literature in Ps 110:3. His exposition of v. 7 is influenced by the same sources (ibid., 158-60). Some scholars detect Egyptian influence upon Psalm 110; see Jean de Savignac, "Essai d'interprétation du psalme cx à l'aide de la littérature Égyptiene,” OTS 9 (1951): 107-35. 
In our layout, an apparently "imbalanced" feature may contain the authorial intent for theological emphasis. Verse 3, as well as the major portion of v. 4, seems to be "imbalanced." Such imbalance might seem surprising for a competent poet such as the one who wrote Psalm 110. The poet's competence has been clearly demonstrated in the song's closely-knit structure. Therefore, we believe this imbalance is the author's original intention to bring out significant theological points. Furthermore, vv. 3-4, through this rhetorical arrangement, indeed contain some theological thrusts that require further investigation. Our observation is further strengthened by the word and syllable count of the poem addressed in the next section.

\subsubsection{A Poetic Study of Psalm 110: Word and Syllable Count}

The word and syllable counts reveal and support what we have concluded regarding vv. 3-4. Table 1 is a list of word- and syllable-count ${ }^{453}$ (the superscription is excluded):

Table 1. Word and Syllable Count of Psalm 110

\begin{tabular}{ccc}
\hline Text & Word count & Syllable count \\
\hline v. 1 & $3: 2$ & $7: 4$ \\
& $3: 2$ & $7: 6$ \\
v. 2 & $5: 3$ & $12: 8^{\mathrm{a}}$ \\
v. 3 & $4: 4: 3$ & $11: 8^{\mathrm{b}}: 7$ \\
v. 4 & $4: 3: 4$ & $9: 7: 7$ \\
v. 5 & $3: 4$ & $8: 9$ \\
v. 6 & $4: 5$ & $10: 7$ \\
v. 7 & $3: 4$ & $6: 5^{\mathrm{c}}$ \\
\hline
\end{tabular}

a This number (8) differs from Fokkelman's count (9). (He adds, to רִ, resultingin 9 syllables. His argument for the addition of the ? is supported by one manuscript and some versions. See Fokkelman, 85 Psalms, 291.)

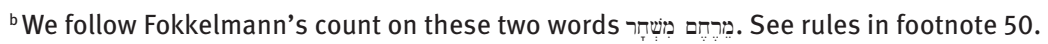

'This number (5) differs from Fokkelmann's (6). (He adds a third personal suffix, ', to the last word in v. 7 based on some textual supports, thus resulting in 6 syllables. See idem, 85 Psalms, 291.)

453 We will compare ours with Fokkelman's. See Fokkelman, 85 Psalms, 459. Our schematic presentation

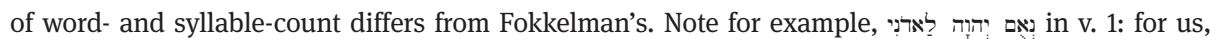
the word- count is 3 and the syllable-count is 7. Fokkelman's schematic presentation is 2.2.3, meaning 3 words and $2+2+3=7$ syllables. Note two rules applied in our project: Segholate nouns are counted as one syllable; and certain auxillary vowels are not counted. Cf. Fokkelman, 85 Psalms, 14-16 and David Howard, Jr., The Structure of Psalms 93-100, BJS 5 (Winona Lake, Ind.: Eisenbraus, 1997), 28-30. 
As one can see above, ${ }^{454}$ the ratio is rather even except in v. 3 and v. 4 . Both have the most word- and syllable-counts: 11 words and 23 syllables. (The runner-up is verse 1: 10 words but 24 syllables.) Thus vv. 3-4 seem to break the "rhythm" of the poem. The poetic devices via word- and syllable-count reinforce the result of our rhetoricalstructural study above, that is, that vv. 3-4 are crucial for the interpretation of the poem. ${ }^{455}$

\subsection{A Poetic-Rhetorical Reading of Psalm 110: Historical or Messianic?}

Critical scholars have often argued against the messianic reading of this poem. ${ }^{456}$ This type of judgment, however, fails to take into account the rhetorical structure of the psalm, and ignores the effect of the final shape of the Psalter concerning this song. Most scholars employ the historical-critical method ${ }^{457}$ - notably strong in historical analysis but markedly weak in the rhetorical-literary understanding of the text - to interpret the Psalter. As observed, the poet has utilized certain poetic devices and techniques (syntax, lexical choice, parallelism, etc.) to bring out his rhetorical effect and thus his theological emphasis in this poem. A look at the rhetorical effect based on the structure of this psalm is needed, and should guide the reader of Psalm 110 into a messianic notion.

454 As pointed out by Fokkelman, syllable counting has been advocated by David N. Freedman, and subsequently followed by two of his students, David Howard, Jr., and Paul Raabe. See Fokkelman, 85 Psalms, 13-14. The major problem with Freedman's method of syllable counting is that his counting is not based on the MT text but is a hypothetically reconstructed text of his own. Thus, his results are very subjective. Dahood points to Freedman's observation that "each stanza [or strophe] contains 74 syllables." Dahood, Psalms 101-150, 113. (There is no bibliographical data in Dahood's commentary for any further verification.) See also a discussion by Howard, The Structure of Psalms, 28-29, in which Howard diverges from his mentor, Freedman, by using the MT text as the basis for his syllable counting.

455 One could still comment, even without any poetic analysis (word-count, etc.), like Alphonse Deissler: "Les v. 3-4 constituent la partie central et essentielle du psaume." Idem, Le Livre des Psaumes: 76-150, vol. 2 (Paris: Beauchesne, 1966), 171.

456 John Goldingay comments on Psalm 110 could serve as representative of the non-messianic interpretation on the psalm: "There is no indication that it speaks of a future king, nor any necessary to reckon that it would be interpreted messianically by the time of the Psalter reached it present form;". See his, Psalms: Volume 3, Psalms 90-150 (Grand Rapids, Mich.: Baker Academic, 2008), 292. (To Goldingay, the messianic interpretation appears only much later in Roman times. See his footnote 20 of bibliography on Mark's messianic interpretation of Psalm 110.)

457 For examples, A. A. Anderson, The Book of Psalms, vol. 2, NCB (London: Oliphants, 1972; reprint 1979), 767-72 for Psalm 110. Dahood, Psalm III, 112-20. 
At the onset of the discussion, a key question that determines how to read this psalm is "who" the person being addressed by Yahweh in vv. 1 and 4 is. ${ }^{458}$ Most scholars agree that the Hebrew word לַארני should be rendered as "my lord" or "my master." ${ }^{459}$ The "you" in the poem from v. $1 b \beta$ to v. $5 a$ is for certain referring to the "lord" in v. $1 \mathrm{~b} \alpha$. It seems that from v. $5 \mathrm{~b}$ to v. 6 , all the third person verbs there should take ${ }^{460}$ (the "Lord," v. 5a) as their subject. ${ }^{461}$ The identity of the "lord" in v. 1 remains murky; therefore, a rhetorical study and an analysis of the composition of the poem may shed light on this identity.

There are several key features the poet, through his compositional skills, uses to describe and define the identity of the person (the lord) in v. $1 \mathrm{~b} \alpha$. Attention is paid to the choice of the lexical item ${ }^{462}$ and the parallel rhetorical structure; both can illuminate the quest for the identity of this person. ${ }^{463}$

\subsubsection{His Rule: The Extent of Time and Location}

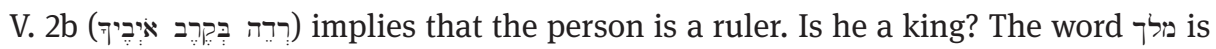
not used in the poem to describe him. ${ }^{464}$ Nonetheless, several hints are dropped that support the claim that the ruler is in fact a king. First, the word ארון is not uncommon when used in reference to a king: Gen 40:1, 1 Sam 24:9[8], 26:17, 2 Sam 3:21, Ps 45:12[11]

458 The parallelism of AA' presupposes that both the oracle of Yahweh (נאט: יחוזה) and the oath of

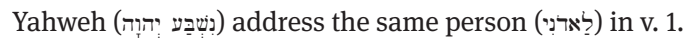

459 To name a few who adopt such rendering: Artur Weiser, The Psalms: A Commentary, trans. Herbert Hartwell, OTL (Philadelphia: Westminster, 1962), 692; cf. VanGemeren, "Psalms," 697 (notes); Allen, Psalm 101-150, 79. Elliot Johnson. "Hermeneutical Principles and the Interpretation of Psalm 110,” BSac 149 (1992): 432-33, 449-52.

460 Allen has listed four options when interpreting this word: (1) as a divine subject, thus equal to Yahweh; (2) as a divine vocative; (3) as a human subject; and (4) as a human vocative. Idem, Psalm 101-150, 82. We prefer the first option as the most viable.

461 If the Lord (equivalent to Yahweh) is the subject, then it may create some incongruent reading for v. 7. Later in this paper, we will reexamine v. 7.

462 See chapter 3 under rhetorical criticism, the theory of style, particularly, lexis.

463 Presumably, we use masculine for the person to be defined and identified.

464 Cf. Tournay, "Le Psaume CX," 7. There he comments: "les mots 'roi', 'royauté' ne sont pas prononcés dan le Ps. Cx." 
and others. ${ }^{465}$ Second, the word (glossed as "scepter") is present in v. 2. Third, the presence of this word ${ }^{466}$ implies kingship to a certain extent. Fourth, the poet citing Melchizedek who possesses the dual status of a king and a priest (cf. Gen 14:18) depicts the person אדון ("lord") in v. 1 as such. To summarize, this person has a royal status even though at times this status might be not be as explicit as one would expect; in other words, the tone is rather subdued. After all, the person's royal status is not assumed ${ }^{467}$ but rather is depicted through the poet's various poetic techniques.

Regardless, his rule is described both in time and location in this psalm. As to time, in v.1, the use of עַ indicates that what follows should be regarded as a "temporal clause": the main verb שישב (imperative) is followed by שישית (imperfect) thereby establishing a consequence with the use of פִֵ The temporal aspect of v. 1 is further

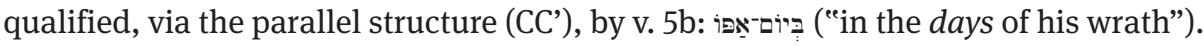
Verse $5 b$ also defines the enemies as being ruled over by this person (CC' and DD'): both "the kings" (v. 5b) and "the nations" (v. 6) seem to oppose the kingly ruler and Yahweh. ${ }^{468}$

In terms of geographical location, v. 2 describes the reign that is from Zion, and the appearance of Zion is foreshadowed by the use of the word הָרם ("footstool"). It occurs six times in the OT and is always in construct with (except 1 Chr 28:2): Isa 66:1, Lam 2:1, Pss 99:5, 132:7 and here. It is a term closely connected to the "Davidark-Zion" tradition ${ }^{469}$ (see Pss 99:2, 132:13 and 110:2 where Zion is found). Therefore, the kingly rule, in the metaphorical sense of "putting enemies under one's footstool,"

465 The verses cited are just a few of the 83 verses resulting from a search with the formula that and אדון occur within the same verse by using the BibleWorks for Windows program. In Gen 40:1, the king of Egypt is described as "lord"; in 1 Sam 24:9[8] and 26:17, David addressed Saul as "my lord, the king"; in 2 Sam 3:21, David is being addressed as "my lord, the king"; in Ps 45:12[11], the king is referred to as "lord." The collocation of these two words strongly suggests that a kingly figure is possible when אדון is used. Of course, the context should provide further support of this possibility. See Doré, "L'évocation de Melchiséech," 21. There he comments on אדון that "c'est un titre qui fait partie du protocole royal." For a similar remark by Raymond Tournay, see "Les relectures du Psalms 110 (109) et l'allusion à Gédéon," RB 105 (1998): 323. Yet there Tournay tones down the term when remarking: "mais ici, il s'agit non d'un messie-roi, commen dans les autres psaumes messianiques, mais d'un prince ... et prêtre."

466 See TWAT 7: 352. There Ps 72:8-9 (cf. v. 1) is quoted to explain the kingly rule ("königliches Herrschen") signified by the presence of this word רדה. Philip J. Nel comments that this word רדה "stresses the act of dominance by force and overlaps accordingly with the comparable nuance of meaning of mšl." See Nel, "רדה," NIDOTTE 3: 1055.

467 Girard in his commentary on Psalm 110 translates v. 1 as "Déclaration de YHWH à mon SEIGNEUR (le roi)." He assumes (Les Psaumes Redécouverts, 160) the "Seigneur" is "le roi" and does not give any argument or proof for this rendering in his essay.

468 The juxtaposition of kings and nations (peoples) could also be found in Ps 2:1-2a. Together they plot against Yahweh and his messianic king (2:2b). The hermeneutical relationship between Psalm 2 and 110 will be explored later in our next two chapters.

469 TDOT 3: 331. 


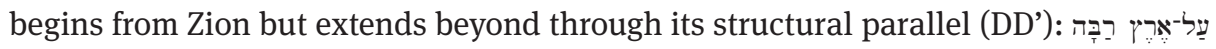
("upon a wide earth" in v. 6b). To recap, the rule of this royal figure has a time-frame that begins with his sitting at Yahweh's right hand and ends when all of his enemies are subjected under his feet; his reign originates geographically in Zion, and extends from Zion and covers an expansive geographical area of the earth.

\subsubsection{His Rule: A Priestly Overtone}

Several key words or phrases are used to describe this ruler. These words are chosen because their nuance depicts this ruler in a blended notion of priest-king. Some of these words, when studied, may have to be viewed syntagmatically or paradigmatically.

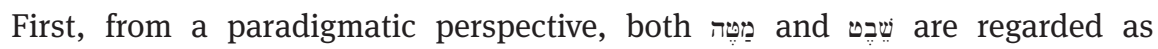
synonyms, ${ }^{470}$ the former chosen over the latter probably because the former contains more of a priestly nuance. For instance, it is used for Aaron's staff in Num 17:21, 23, $25[6,8,10]$ and later in Numbers 25, when God made a covenant of "a lasting

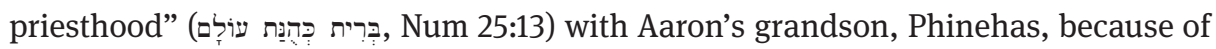
his zeal for the Lord. Consequently, the word מַט or priesthood. The poet decided on פַט to be used in Psalm 110 because the ordination of the priesthood will be given to the ruler a few verses later in the poem. In other words, the poet deliberately chose this word in the psalm due to the following context, v. 4b, especially signified by this phrase כהון לִעוָֹם ("priest forever"; cf. Num 25:13 above). Strikingly, the priesthood is now in accordance with the order of Melchizedek, not of Aaron.

Second, the word הָדָר, glossed as a "sacred, festal garment"471 especially in Ps 110:3, is used to foreshadow the priestly notion later in the psalm. When it (feminine form) is used in Ps 29:3, 96:9, 1 Chr 16:29 and 2 Chr 20:21 with קדּש

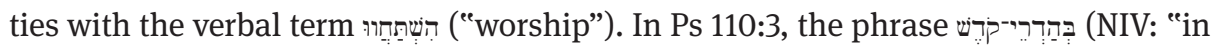
holy majesty") implies an army of priests, just as Briggs comments: "[It is] always used in connection with public worship of Yahweh and implies priestly ornaments." 472 C. John Collins comments that this phrase should be rendered "'in ornaments (ornamental garments?) of holiness,' describing the attire of the king's troops." ${ }^{\text {'43 }}$

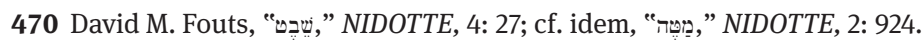

$471 B D B, 214$.

472 Briggs, Book of Psalms, 379.

473 C. John Collins, "הרר," NIDOTTE, 1: 1015. 
Many, however, have attempted to change the reading of בהררי to ("mountains") with some textual support (please see our textual note of this phrase in "Textual Notes for Psalm 110” in this chapter). Should it be read as בהדרי (as the MT) in light of

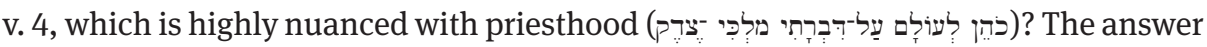
is probably yes, because the poet has reinforced the "priestly" idea through the consonantal play of בברתי and (in v. 4).

Hence, the use of מטר prepares the reader for v. $4 .{ }^{475}$ In other words, the poet, by carefully and deliberately choosing certain words affecting a priestly nuance, has already hinted that the ruler is also a priest.

Third, v. 4b undoubtedly contains a "priestly" (אתה-כהן) overtone. The word אָתָה ("you") refers back to לַארנִ (v. 1), to whom his enemies will be subdued and to whom the scepter of power is given (v. 2). But now the ruler is appointed, under a divine oath, ${ }^{476}$ as "מהן לְעוֹלָם "priest forever." For our poet, the only antecedent example in the biblical text where a ruler/king could also be a priest is Gen 14:18-20 where ("Melchizedek") appears. Therefore, it is appropriate for the poet to pen the phrase

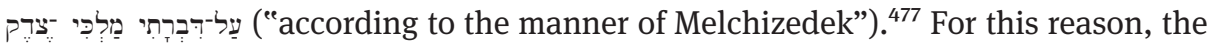
MT reading for $\mathrm{v}$. $4 \mathrm{~b}$ should be maintained.

474 See the apparatus of BHS. Allen, Psalm 101-150, 79 and his discussion in note $3 d$ in p. 80. Cf. Howard, Structure of Psalms, 89. There he discusses the term "footstool," "Zion" and the phrase in Psalm 99. For two reasons, William P. Brown challenges any emendation but to retain the MT reading: (1) its priestly and cultic tone, a parallel to the royal office in v. 2 and (2) because the MT is a more difficult reading. See Brown, "A Royal Performance: Critical Notes on Psalm 110:3ay-b," JBL 117 (1998): 96 (footnote 21).

475 The use of this word נדָבת (v. 3) contains also a cultic idea. It occurs in Lev 7:16, 22:18, 21, 23 and 23:38. It syntagmatically ties to נירֶ.

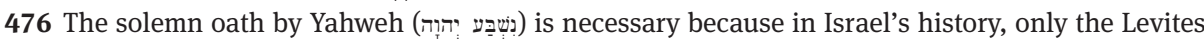
are entitled to the priesthood. The divine oath now changes the order of priesthood from Levites to a royal priesthood. The author of Hebrews offers an insightful exposition of this psalm; cf. Heb 7:11-21, particularly vv. 20-21. See chapters ten and eleven of this project.

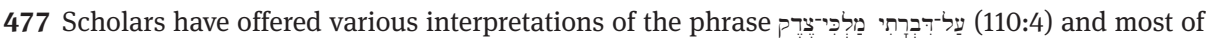

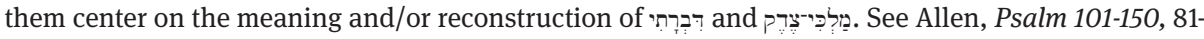
82, who cites 13 works. Since studies on Psalm 110 are voluminous (besides Allen's bibliography and ours in chapter one), we add to those who respect the MT reading (supported by the LXX), listed in chronological order: Delitzsch, The Psalms, 183, cf. 192-93; J. J. Stewart Perowne, The Book of Psalms, vol. 2 (London: George Bell and Sons, 1878; reprint, Grand Rapids, Mich.: Zondervan, 1976), 311; Edward J. Kissane, "The Interpretation of Psalm 110," ITQ 21 (1954): 103, cf. 114; John L. McKenzie, "Royal Messianism," CBQ 19 (1957): 34; G. R. Driver, "Psalm CX: Its Form Meaning and Purpose," in Studies in the Bible: Presented to Professor M. H. Segal, ed. J. M. Grintz and J. Liver, ISBR 17 (Jerusalem: Kiryat Sepher, 1964), 28; Hans Strauss, Messianisch ohne Messias: Zur Überlieferungsgeschichte und Interpretation der sogenannten messianischen Texte im Alten Testament, EH 232 (Frankfurt: Peter Lang, 1984), 17; M. J. Paul, "The Order of Melchizedek (Ps 110:4) and Heb 7:3," WTJ 49 (1987): 202-203; Willem van der Meer, "Psalm 110: A Psalm of Rehabilitation?," in The Structural Analysis of Biblical and Canaanite Poetry, ed. van der Meer and Johannes C. de Moor, JSOTSup 74 (Sheffield: JSOT Press, 1988), 228; Seybold, Die Psalmen, 437; Kurianal, Our High Priest, 56-57. 
Fourth, the consonantal play (the switch between letters $\pi$ and $\urcorner$ ) of these two words, הדר and רדה should be noted theologically. More specifically, do they entertain the notion of a messianic reading? For the word רự, Audrey Johnson remarks:

The choice of the comparatively rare verb hd'r' to denote the rule, which is to be exercised by the 'Messiah', coming as it does within so clear an example of a prophetic oracle, becomes the more interesting when it is seen that the ruler in question is to wield authority in terms of the ancient priesthood of Melchizedek. ${ }^{478}$

Will both words reinforce a messianic interpretation of a kingly priest? The answer is positive because of the unique word מִשְָׁ (see the following).

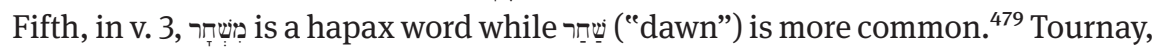
משיח as possible paronomasia with ("anointed"), משחר 480 argues validly and effectively. First, if Ps 110 is compared with Psalm 2, both contain many verbal similarities and address similar theological concerns. ${ }^{481}$ For instance, in Ps 2:6, the messianic king will rule in Zion (cf. 2:2), which is exactly the same idea conveyed in Ps 110:2. Second, we have already demonstrated that the poet of this psalm is a skillful master of word- and sound-play. ${ }^{482}$ Techniques like "paronomasia" would be welcome in the poet's construction of this song. ${ }^{483}$

Though it is a dangerous practice to build any theology on a mere few words, the presence of these words is significant to draw out the meaning of Psalm 110. The ruler, signified by מטה (and), is also portrayed as a priest in the presence of the words מטהה, and possibly נדברי anis kingly priest matches the figure of Melchizedek in Gen 14:18-20. From the historical perspective, no such person had ever appeared in

478 Audrey Johnson, The Cultic Prophet and Israel's Psalmody (Cardiff, England: University of Wales Press, 1979), 82.

479 Th. Booij interprets it from the ancient Near Eastern concept of the "sun." We disagree with his interpretation (see our following discussion). See Booij, "Psalm CX: 'Rule in the midst of your foes!'," VT 41 (1991): 399-401.

480 See Tournay, Seeing and Hearing, 213. Furthermore, Schaper sees that the use of the Greek word

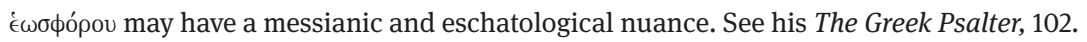

481 Further discussion of the semantic-thematic relationship of these two psalms is found in our next two chapters.

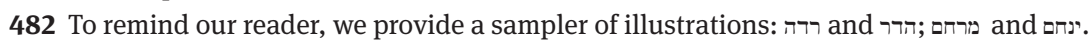

483 In addition, the shape of the Psalter also illuminates our interpretation. See our next two chapters. 
Israel so the "only probable solution is that the psalm speaks about a future priestking. It deals not with a historical king, but with the messiah." 484

This messianic interpretation is set in a prophetic tone. That is, the use of this phrase נאם יהוה in this psalm sets the stage for readers to depart from a mere historical reading of this text. Even behind this psalm's Sitz im Leben of an enthronement occasion, which is still considered to be inconclusive, this "introductory formula of prophetic revelation" ${ }^{485}$ signals an eschatological reading of the person being addressed and described (לַאדני) in the psalm.

484 Paul, "Order of Melchizedek," 202. Some see that David and/or Solomon come very close to the king-priest notion in Psalm 110. For example, van der Meer comments: "A study of kingly functions significantly reveals that David and Solomon are described as fulfilling priestly functions. ... These facts are sufficient to demonstrate that in any respect, in the offices of David and Solomon, a priestly, mediatorial role is present" ("Psalm of Rehabilitation," 228-29). (See authors cited by van der Meer in footnote 65 on p. 229 to support his assessment.) In our critique, we respond that fulfilling some priestly functions does not make one a priest (cf. 2 Sam 6:13-14, 17). Neither David nor Solomon was called "priest" (but they are labeled "king") in the biblical text. Perhaps thinking along the same lines, Bowker sees this psalm (plus Genesis 14) as David's attempt to unify the tribes under his reign while Rowley sees in this psalm David's justifying the installation of the Zadok priesthood in Jerusalem. See J. W. Bowker, "Psalm CX," 31-41 and H. H. Rowley, "Melchizedek and Zadok (Gen 14 and Ps 110)," in Festschrift: Alfred Bertholet zum 80. Geburtstag, ed. W. Baumgartner O. Eissfeldt, K. Elliger and L. Rost (Tübingen: Mohr, 1950), 461-72 respectively. (We have also noted a similar projection in Genesis 14 in our fourth chapter.) Both views reconstruct a history based on the text and perhaps may go beyond what the text warrants. Nonetheless, the skillful poet of Psalm 110 is not merely influenced by the historical factor, but is also inspired by the literary influence of Genesis 14 (and its cotexts). Our next two chapters will prove this notion. We use small "m" for "messiah" since in the OT times that person had not been identified. Only later in the NT times was Jesus given the title "Messiah." E. Lipiński reconstructs the history behind this poem (especially vv. 4-5) based on 1 Kings 2; the contention between two potential king candidates, Solomon-Adonijahin, and two potential high priest candidates, Abiathar-Zadok. Idem, Étude sur des Textes 'messianiques' de l'Ancien Testament," Sem 20 (1970): 56-57. Such reconstruction, however, fails to account for the rest of the poem, vv. 5-6, for example. More radically, Gillis Gerlman interprets this psalm in light of the life of Judah (and Tamar) and the blessing to Judah in Genesis 49. Gerlman, "Psalm CX," VT 31 (1981): 1-19. While we commend Gillis' innovation, we reject some of his unwarranted conjectures of the text. For example, Gillis interprets this phrase שִב לִימִינִ as "Bleib ruhig in meinem Südland" (p. 4, cf. p. 16).

485 Allen, Psalms 101-150, 80. There he notes that the other place where occurs in Psalms is 36:2[1]; however, the phrase נאם יהוה is unique in the Psalter even though it is very common in the OT prophetic literature (e.g., Isa 43:10, Jer 1:8, etc.). Cf. D. Vetter, "נאם,", in TLOT, 2: 693. In a broader context, and as far as our interest in this project extends, this word links to our cotexts of Genesis 14 (i.e., Gen 22: 16) and Numbers 22-24 (Num 24:3, 15, etc.); both are outside of the OT prophetic literature. In our poeticstructural analysis, נאם יהוה לאדני is parallel to נשבע יהוה ולא ינחם (AA'). The latter adds some weight to the prophetic nature of the former by casting it in a solemn oath by Yahweh. 


\subsubsection{His Supernatural Birth}

Given that the messianic reading is feasible as delineated above, v. 3 should then be examined from an eschatological/messianic perspective. It is true that v. 3 seems to be "fairly mythical." ${ }^{486}$ As to this verse, the following are possible English renderings ${ }^{487}$ based on the major textual variants:

(1) Your people are willing in the day of your strength in holy array from the womb of the morning to you (like) dew (is) your youth

(2) Your people are willing in the day of your strength in holy mountains ${ }^{488}$ from the womb of the morning to you (like) dew (is) your youth

(3) Your people are willing in the day of your strength in holy array from the womb of the morning $<$ to you (like) dew> ${ }^{489}$ I give birth to you ${ }^{490}$

(4) Your people are willing in the day of your strength in holy mountains from the womb of the morning $<$ to you (like) dew $>$ I give birth to you

(5) With you (is) nobility ${ }^{491}$ in the day of your strength in holy array from the womb of the morning to you (like) dew (is) your youth

(6) With you (is) nobility in the day of your strength in holy mountains from the womb of the morning to you (like) dew (is) your youth

(7) With you (is) nobility in the day of your strength in holy array from the womb of the morning $<$ to you (like) dew> I give birth to you

486 Booij, "Psalm CX," 401.

487 A discussion of the English translations of Psalm 110 can be found in Robert Bratcher and William Reyburn, A Handbook on Psalms (N.Y.: United Bible Societies, 1991), 947-53.

488 The reading "mountains" is supported by Targum, Symmachus and Jerome.

489 Words inside < > are lacking; here it refers to the LXX.

490 "I give birth to you" is a LXX reading.

491 It is a Septuagintal reading. 
(8) With you (is) nobility in the day of your strength in holy mountains from the womb of the morning $<$ to you (like) dew $>$ I give birth to you

Readings (1) and (2) place the "people" (עِ as the focus with their textual witnesses all Hebraic; one word in (2) is Targumic. Readings (3) and (4) will split the focus into two: "people" for the first part of the verse while "you" for the rest of v. 3. Both are hybrid readings; the last partof v. 3 and v. 4 adopts the LXX reading. Readings (5) through (8) all have "you" as focus but (5) and (6) reflect hybrid textual supports: (5) with a LXX reading and (6) with a LXX reading and a Targumic reading. Both (7) and (8) readings consistently adopt the LXX reading but (8) contains a Targumic word ("mountains").

Reading (7) is preferred for two reasons. First, its variant readings reflect consistent textual traditions; all its variant readings are Septuagintal and it is important that they do not involve any change of the MT consonantal text. Second, the reading has a semantic congruence: "nobility" with "holy array" and "womb" with "giving birth."

דך טל The phranting in the LXX, 492 is difficult to interpret and has rendered v. 3 unintelligible. Nonetheless, it could still makes sense if it is read as לך לד based on the Syriac Version. 493 The word של can mean "child" in the Aramaic sense according to Kissane. ${ }^{494}$ The Aramaic element (טלי) should not surprise any interpreter because in Ps 2:12, an Aramaic word ("son") appears, also in the context of birth (ילידתיז in Ps 2:7). Accordingly, the meaning of v. 3 can be rephrased as follows: "With you (is) nobility, in the day of your strength, in holy array, from the womb of the morning, to you (like) a child, I give birth to you." In other words, the priest-king, who is in power, is from noble rank, with holy splendor. He is messianic with a supernatural

492 Allen points out that the omission by the LXX "is probably due to the translator's inability to understand the words in their contexts" (Psalm 101-150, 81).

493 Booij attempts to change the reading למשל to (") לד טל ("as a ruler") are not plausible since the reading lacks textual support ("Psalm CX," 398). Likewise, Brown adds a "ך" before (assuming

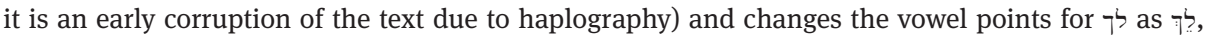
so the phrase is לד כטל, rendered as "go forth, like [the] dew." Brown, "A Royal Performance," 95-96. Likewise, his proposal lacks textual support, and he commits the same mistake as Booij.

494 Kissane, "Interpretation of Psalm," 109. Similarly, Delcor argues: "Verse 3b, which is particularly difficult, seems to describe the begetting of the king by the intervention of Yahweh. . . By this it must presumably be understood that the king has been adopted as the son of God. לד לד ליר יל 'you as

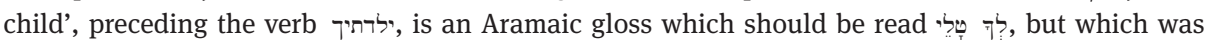
subsequently misunderstood as Hebrew ('to you the dew'). The Syriac version has indeed grasped the meaning of this Aramaic gloss by translating: 'for a long time I have begotten you as a child'." See his "Melchizedek from Genesis," 121. 
birth. ${ }^{495}$ Such idea fits the overall flow of the context since "you" (not "your people") has been the focus in this poem, particularly when we come to v. 4 with the emphatic use of אתָז ("you").

\subsubsection{His Life of Human Nature}

If v. 3 is read this way, it helps us to explain v. 7 because the nature of v. 3 "supernatural" (perhaps a mystical) sense of the high birth of a priest-king - needs to be balanced. Clearly v. 7 is capable of balancing exactly the "supernatural" or "divine" sense by providing a "human" nature rendered semantically "he drinks from the brook." Therefore, some analysis of this verse is required. ${ }^{496}$

The interpretation of v. 7 hinges solely on "who" is the subject of these verbs. We have already noted that the subject for the verbs in vv. 5-6 is Yahweh. Furthermore, according to the descriptions in these two verses, no human figure could accomplish these things. This reasoning leads to the question: is Yahweh still the subject of the verbs in v. 7? Our rhetorical-poetic analysis has shown that ראי "head" serves as an

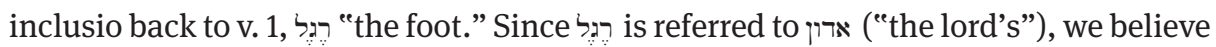
the head here also refers to the same person, that is ארון. ${ }^{497}$ In the final analysis, the purpose of this verse is to bring out the human side of this messianic king, thereby balancing his supernatural side set forth in v. 4.

\subsection{Conclusion}

Our poetic analysis has pointed out the "un-parallel elements" in vv. 3-4. Although v. 3 is extremely difficult to interpret, our poetic examination has helped us render this verse in a more meaningful way, and our understanding does not violate or

495 Cf. Hay holds a similar view based on rabbinic interpretation; idem, The Right Hand, 27-33, especially p. 32.

496 Joachim Becker has given an extensive survey of how v. 7 is being interpreted (and the text being reconstructed) by various scholars. He then offers his own interpretive version that the verb "drink" has an elliptical object "blood," according to his analysis of some biblical and ANE texts. Becker, "Zur Deutung von Ps 110,7," in Freude an der Weisung des Herrn: Beiträge zur Theologie der Psalmen, ed. Ernst Haag and Frank-Lothar Hossfeld (Stuttgart: Katholisches Bibelwerk GmbH, 1986), 17-31. Also cf. Tournay, "Les relectures du Psalms," 321-31, in which Tournay interprets v. 7 in light of Gideon's triumph against the Midianites. Cf. VanGemeren, "The Psalms," 700.

497 One should not be surprised by an abrupt change of speaker or person in some psalms even within a verse or two. For example, N. H. Ridderbos, observing Psalm 2:6-7, comments that there is an abrupt change of "subject" in these two verses. See his Die Psalmen: Stilistische Verfahren und Aufbau mit besonderer Berücksichtigung von Ps 1-41, BZAW 117 (Berlin: Walter de Gruyter, 1972), 74. 
run counter to the main theme of this poem. The theological theme of this poem is embodied in v. 4: the messianic figure is not just a ruler (king) but is also a priest. Although this priest-king concept was first manifested in the person of Melchizedek, our poet, by his skillful poetic techniques, permeates the text with the same theological thrust because the poet knows that merely citing an ancient name (Melchizedek) is insufficient if he wants to powerfully and rhetorically make his point. By the poet's artistic composition of this poem, he tries to bring out the eschatological and messianic elements of this figure: his kingly rule (v. 2 and vv. 5-6) as well as his priestly function (v. 3a) with a divine birth (v. 3b) balanced by a human nature (v. 7).

Granted that we have read Psalm 110 messianically, can we sustain such reading in view of the cotexts of Psalm 110? In our next two chapters, we will verify such reading as we study the Psalter as cotexts for Psalm 110. 